\title{
SOCIAL HERMENEUTICS STUDY ON THE MEANING OF JIHAD BY STUDENTS OF MULAWARMAN UNIVERSITY
}

\author{
STUDI HERMENEUTIKA SOSIAL TENTANG MAKNA JIHAD \\ MENURUT MAHASISWA UNIVERSITAS MULAWARMAN
}

\author{
Langgeng Saputra ${ }^{1}$, Sri Murlianti ${ }^{2}$, Martinus Nanang ${ }^{3}$ \\ Universitas Mulawarman, Indonesia \\ Email Correspondence: putra.bgln@gmail.com
}

\begin{abstract}
:
Jihad has been an integral part of Islamic discourse from its early days until today. This research was conducted to determine variations in the meaning of jihad that developed in Mulawarman University students. I use Paul Ricoeur's theory of Social Hermeneutics to explain how the process of interpreting meaning from a text. Ricoeur views that text has a life of its own regardless of the author's intention or intent (text autonomy). In interpreting the text, Ricoeur also argues that understanding and explanation are not two contradictory methods of interpreting the text. The workings of Paul Ricoeur's social hermeneutics include three factors, namely the world of text, the world of presenters, and the world of readers, whereas in this paper there are only two factors, namely the world of text and the world of readers. Jihad in al-Qur'an is repeated 41 times in 23 verses and by Ibn Al-Qayyim it is divided into four meanings, namely jihad against lust, jihad against Satan, jihad against infidels, and hypocrites, and jihad against injustice and wickedness. Meanwhile, readers only divide jihad into two meanings, namely jihad against lust and war jihad. In the process of interpreting, readers are greatly influenced by the trajectories of life that they have been through. This can be seen from the many meanings of jihad they express, namely war, defending, doing good, effort/strength, being serious, preaching, and enthusiasm.
\end{abstract}

\section{Keywords: Islam, Jihad, Social Hermeneutics}

\begin{abstract}
ABSTRAK:
Jihad merupakan bagian integral wacana Islam sejak masa awal kedatangannya hingga sampai saat ini. Penelitian ini dilakukan untuk mengetahui variasi makna jihad yang berkembang pada Mahasiswa Universitas Mulawarman. Teori Paul Ricouer tentang Hermenutika Sosial saya gunakan untuk menjelaskan tentang bagaimana proses menafsir sebuah makna dari sebuah teks. Ricouer berpandangan bahwa teks memiliki kehidupannya sendiri terlepas dari intensi atau maksud pengarang (otonomi teks). Dalam menginterpretasi teks, Ricoeur juga berpendapat bahwa pemahaman dan penjelasan bukanlah dua metode yang bertentangan dalam menafsirkan teks. Cara kerja hermenutika sosial Paul Ricoeur mencakup tiga faktor yaitu dunia teks, dunia pemateri dan dunia pembaca sedangkan dalam tulisan ini hanya ada dua faktor yaitu dunia teks dan dunia pembaca. Jihad dalam al-Qur'an terulang 41 kali dalam 23 ayat dan oleh Ibn Al-Qayyim dibagi menjadi empat makna, yakni jihad melawan hawa nafsu, jihad melawan setan, jihad memerangi kaum kafir dan kaum munafik serta jihad melawan kezaliman dan kefasikan. Sedangkan pembaca hanya membagi jihad dalam dua makna yakni jihad melawan hawa nafsu dan jihad perang. Dalam proses penafsirannya, pembaca sangat dipengaruhi oleh trajektori kehidupan yang mereka pernah lalui. Hal ini dapat dilihat dari banyaknya makna jihad yang mereka ungkapkan, yaitu perang, membela, melakukan kebaikan, usaha/kekuatan, bersungguh-sungguh, dakwah serta semangat.
\end{abstract}

\section{Kata Kunci: Hermeneutika Sosial, Islam, Jihad}

\begin{tabular}{l|l|l|}
\hline Article Info & & \\
\hline Received & $:$ & January 2021 \\
\hline Accepted & $:$ & January 2021 \\
\hline Published & $:$ & January 2021 \\
\hline DOI & $:$ & https://doi.org/10.30872/psd.v2i1.23 \\
\hline
\end{tabular}

\section{Copyright and License}

Authors retain copyright and grant the journal right of first publication with the work simultaneously licensed under a Creative Commons Attribution 4.0 International License that allows others to share the work with an acknowledgment of the work's authorship and initial publication in this journal. 


\section{PENDAHULUAN}

Dewasa ini penggunaan tema jihad hampir-hampir menimbulkan persepsi yang mengandung unsur peyoratif. Kedekatannya dengan pelegitimasian penggunaan kekerasan memunculkan metafor-metafor lain sebagai tangan panjang dari jihad. Radikalisme, fundamentalisme dan terorisme adalah stereotype yang selalu diberikan Barat (sebutan Negara di Benua Eropa dan Amerika) untuk memvisualisasikan citra Islam di mata dunia. Perlu diketahui bahwa pelabelan negatif atas Islam ini, semata-mata terdorong oleh ketakutan Barat akan ancaman Islam global yang oleh Esposito disebut dengan istilah Green Menace (bahaya hijau) melalui revolusi berdarahnya mengingat jargon jihad mampu memberikan pengaruh psikologis dan emosional bagi mobilisasi umat Islam di setiap negara- negara di seluruh dunia. Akibatnya akan muncul kebijakan pemerintah yang secara sepihak berlaku represif (keras) terhadap umat Islam yang justru akan memacu semangat radikalisasi yang dapat mengakibatkan skeptisme terhadap demokrasi dan menganggap "kekerasan" merupakan satu-satunya cara (Esposito, 1997: 28).

Jihad yang merupakan bagian integral wacana Islam sejak masa-masa awal kedatangannya hingga sekarang telah melahirkan pendapat dan pandangan yang bervariasi. Polemik tentang jihad semakin beragam ketika para tokoh memandang dari sudut pandang yang berbeda dan dari latar belakang yang berbeda pula. Pemaknaan jihad semakin sensitif dan sering disalah pahami terutama oleh para pemikir Barat (orientalis) yang memandang jihad sebagai "perang suci", (Azra, 1996: 127-128) yaitu perang untuk menyebarluaskan agama dengan melegitimasi penggunaan kekerasan. Mereka berasumsi bahwa ruh jihad memiliki persamaan doktrin dengan perang salib (crusades). Padahal dalam konsep Islam, jihad dalam arti perang, tidak dibenarkan menggunakan kekerasan secara absolut atau mutlak. Dalam hal ini perang merupakan tindakan solusif yang merupakan alternatif paling akhir dalam misi universalitas Islam dalam memperbaiki tatanan sosial dengan penerapan kedaulatan syari'ah, dengan catatan tidak untuk memaksa keimanan seseorang (Azra, 1996: 158). Pelaksanaan jihad sebagai perang suci yang kemudian melahirkan sebuah pandangan tentang Islam sebagai "agama pedang" telah mereduksi makna bathini dan spiritual jihad (Nasr, 1994: 19).

Di sisi lain, secara sosiologis ada kegelisahan di kalangan umat Islam terhadap adanya kesenjangan antara realitas dengan ajaran ideal Islam. Satu sisi, Islam diyakini sebagai agama yang cinta perdamaian, kasih sayang, toleran, dan menghargai terhadap setiap perbedaan termasuk perbedaan agama dan keyakinan. Bentuk-bentuk pemaksaan dan kekerasan bertentangan dengan ajaran Islam. Tetapi pada sisi lain, sulit dibantah bahwa dalam Islam ada ajaran "jihad" yang bisa dipahami dan diartikan dengan perang (dalam pengertian khusus). Hal ini kemudian mendorong banyak aksi-aksi kekerasan akibat dari pengkajian yang tidak sempurna terhadap ajaran Islam. Keterlibatan jihad semakin melenceng dari konsep semula (awal perintah jihad), ketika kehadiran jihad dijadikan komoditas politik untuk menghancurkan lawan politik. Adapun kemunculan Laskar Jihad beberapa waktu yang lalu, seperti kelompok Santoso hingga kemunculan Islamic State of Suriah and Irak (ISIS) cukuplah mewakili berbagai penyimpangan- penyimpangan terhadap norma-norma berjihad dalam melawan kemungkaran/kejahatan yang terjadi dewasa ini (http://news.liputan6.com). Sebagian pengamat politik di tanah air mengkhawatirkan adanya kelompok- kelompok parsial tertentu yang berusaha memboncengi niat mereka untuk berjihad fii sabilillah (berjuang karena Allah) dengan alasan-alasan politik yang justru akan menguntungkan kelompok parsial tersebut.

Universitas Mulawarman, disingkat Unmul adalah perguruan tinggi negeri di Samarinda, Kalimantan Timur. Universitas ini berdiri pada tanggal 27 September 1962, sehingga merupakan universitas tertua di Kalimantan Timur. Universitas Mulawarman juga merupakan perguruan tinggi dengan jumlah mahasiswa terbesar di Kalimantan, yaitu lebih dari 37.000 orang (www.unmul.ac.id). Dengan banyaknya mahasiswa di Universitas Mulawarman maka terdapat berbagai latar belakang keilmuan dan organisasi kemahasiswaan baik yang berbasis agama dan lainnya. Dengan latar belakang yang beragam tadi, maka akan banyak makna jihad yang berkembang di kampus Universitas Mulawarman, seperti halnya terjadi pada tahun 2013 ketika terjadi kerusuhan Pemilihan Raya BEM-KM Unmul, salah satu organisasi mahasiswa mengatakan bahwa mereka melakukan jihad dalam melakukan perlawanan kepada pihak yang menolak kegiatan Pemira. Lain pula dengan Pusat Studi Mahasiswa Islam Universitas Mulawarman yang mengatakan bahwa syiar agama yang dilaksanakan juga merupakan jihad fii sabilillah.

Dari uraian dan gambaran di atas penulis melihat adanya berbagai pemaknaan berbeda tentang memaknai jihad, sehingga menimbulkan berbagai pertanyaan tentang makna jihad itu sendiri. Pertanyaan dan rasa ingin tahu ini menjadi topik utama dalam penulisan ini, yakni menginterpretasi makna jihad menurut mahasiswa di Universitas Mulawarman.

\section{METODE}

Penelitian ini menggunakan metode penelitian hermeneutika sosial. Kerja hermeneutika mencakup tiga faktor di dalamnya, yaitu (1) dunia teks (isi dari teks), (2) dunia pemateri (pengarang atau pencipta teks) dan (3) dunia pembaca (Ricouer dalam Richard, E. Palmer. 2003: 8). Kerja hermeneutika mencakup tiga faktor, salah satunya ialah dunia pemateri. Dunia pemateri yang dimaksud ialah pencipta teks yang 
memfirmankan/mengatakan ayat tentang jihad yakni Allah SWT dalam kitab suci al-Qur'an, sehingga pada penelitian ini peneliti hanya mampu menjangkau 2 (dua) dari 3 (tiga) elemen tersebut, yakni dunia teks dan dunia pembaca.

\section{HASIL DAN PEMBAHASAN}

Dalam interpretasi makna jihad pembaca, saya mendapati dua makna dari empat teks makna jihad dalm al-Qur'an. Pertama, pembaca memaknai jihad sebagai suatu perang yang dalam teks al-Qur'an dimaknai sebagai jihad memerangi kaum kafir dan kaum munafik dan jihad melawan hawa nafsu.

\subsection{Jihad Memerangi Kaum Kafir dan Kaum Munafik}

Jihad memerangi kaum kafir dan kaum munafik dalam teks al-Qur'an dimaknai sebagai jihad perang oleh Aldi dan Andri. Aldi memaknai jihad dari dua makna, makna bahasa dan makna syar'i. Menurutnya jihad dalam bahasa ialah bersungguh-sungguh sedangkan makna syar'i ialah qital atau perang. Selanjutnya ia menjelaskan kembali bahwa qital (perang) mempunyai bentuk yang ofensif dan defensif. Jihad ofensif adalah jihad yang dilakukan untuk menyerang kaum kafir dan kaum munafik yang menghalangi berkembangnya ajaran agama atau jihad yang dilakukan untuk mengajak kaum kafir untuk masuk Islam. Apabila mereka menolak dakwah Islam maka mereka ditawari membayar jizyah (pajak), apabila menolak mereka diperangi. Sedangkan jihad defensif adalah jihad yang dilakukan dalam rangka untuk mempertahankan diri.

Dari penjelasan yang disampaikan oleh Aldi, ia mengambil kesimpulan bahwa jihad merupakan sebuah kaidah hukum syariat. Artinya jihad merupakan peranan negara yang dilakukan untuk menjalankan hukum secara syar'i. Sehingga jihad bagi Aldi ialah perang yang hanya dapat dilakukan secara maksimal oleh sebuah negara baik secara ofensif dan defensif.

Selanjutanya Andrie yang merupakan junior dari Aldi dalam ormas mahasiswa Gema Pembebasan juga memaknai jihad sebagai suatu perang. Andrie memahami perintah jihad dilatarbelakngi oleh adanya orangorang kafir yang mengahalagi ketika awal-awal perkembangan Islam di Kota Mekkah. Jihad adalah mengerahkan segenap kemampuan dalam perang dijalan Allah baik secara langsung berperang maupun hanya memberikan bantuan perang. Selanjutnya ia menjelaskan bahwa setelah runtuhnya khilafah, jihad tidak diartikan dalam konteks sebenarnya. Contohnya ia tidak sependapat bahwa memerangi korupsi merupakan sebuah jihad, karena sama sekali tidak berkorelasi dengan makna jihad yang ia pahami.

\subsection{Membela}

Gusti memaknai Islam lebih sebagai kepercayaan dibandingkan hanya sebuah agama. Menurutnya Islam itu rahmatan lil alamin (rahmat bagi seluruh alam). Jihad dalam pandangannya didasari karena kondisi perpolitikan pada saat awal perkembangan Islam di zaman Nabi. Dimana Islam merupakan ancaman bagi bangsa-bangsa lain sehingga wajib diperangi. Selanjutnya ia mengatakan konsespsi jihad ialah membela. Pada zaman Nabi kita diwajibkan membela Islam dari serangan atau ancaman bangsa lain seperti Yahudi. Namun sekarang konsepsi jihad digunakan untuk manusia sebagai wujud interpretasi Tuhan. Artinya bahwa manusia haruslah menjihadkan sifat-sifat Tuhan seperti sifat Tuhan yang maha pengasih, maha penyayang dan sebagainya.

\subsection{Melakukan Kebaikan/Jalan Kebaikan/Menyeru yang Makruf}

Jihad melawan hawa nafsu selanjutnya dimaknai pembaca untuk melakukan kebaikan, sebuah jalan kebaikan ataupun menyeru pada yang makruf. Hani yang merupakan mahasiswa kedokteran memaknai jihad dari sebuah ayat al-Qur'an yang menyerukan untuk berjihad dijalan Allah baik dalam keadaan berat ataupun ringan. Ia mengartikan bahwa jihad dapat dilakukan dengan melakukan kegiatan- kegiatan baik yang diniatkan kepada Allah seperti kuliah, bekerja, belajar dan berdagang yang diniatkan karena Allah. Ia melanjutkan kembali bahwa menjauhi kemungkaran yang diniatkan karena Allah termasuk jihad. Dalam konteks sekarang, Hani memaknai jihad dengan memaksimalkan peran yang kita miliki, contohnya mahasiswa dapat berjihad dengan menyuarakan aspriasi untuk kepentingan rakyat ataupun belajar karena diniatkan karena Allah.

Hampir sama dengan Hani, Nurul juga memaknai jihad sebagai sebuah jalan kebaikan. Ia juga berpendangan bahwa Islam adalah identitas yang mengajarkan kebaikan serta kebenaran. Sehingga jihad baginya adalah bagaimana cara kita menuju jalan kebaikan seperti halnya menolong orang lain. Ia tidak begitu paham tentang awal mula jaran jihad hadir didalam agama Islam. Ia hanya memahami bahwa ajaran jihad lahir dari sebuah perjuangan untuk membela sesuatu yang benar.

Rudini juga mengatakan bahwa jihad yang sebenarnya adalah jihad melawan hawa nafsu. Islam baginya adalah sebuah keselamatan dan mengajarkan kesalamatan, maka Islam ini bukan milik sebagian orang tapi milik umat manusia yang ada di dunia. Ia melanjutkan bahwa jihad adalah takmuuruna bil ma'ruf watanhaunal anil munkar. Artinya jihad adalah menyeru pada yang makruf (kebaikan) dan mencegah dari kemungkaran. Contohnya adalah jihad yang dilakukan oleh mahasiswa ialah mencari ilmu. 


\subsection{Usaha/Kekuatan}

Jihad melawan hawa nafsu selanjutnya dikatakan sebagai usaha atau kekuatan. Menurut Heni ajaran jihad lahir sejak pada zaman Nabi Muhammad saw dimana banyak orang kafir yang mengganggu atau menentang Nabi Muhammad saw untuk menyebarkan agama Islam. Jihad baginya merupakan usaha atau kekuatan, walaupun ia tahu bahwa ajaran jihad ada karena untuk melawan orang kafir yang menghalang-halangi ajaran Islam. Heni pun memberi contoh bahwa membelanjakan harta kita di jalan Allah swt merupakan sebuah usaha atau kekuatan untuk berjihad melawan hawa nafsu.

Kemudian Wahyu juga menjelaskan bahwa jihad berasal dari kata juhdun yang artinya usaha atau kekuatan. Jihad tidak hanya dapat diartikan sebagai perang yang ada seperti ketika di zaman Nabi Muhammad saw dan sahabat. Tapi dapat diartikan sebagai usaha dengan segenap kemampuan kita untuk berbuat kebaikan yang diniatkan karena Allah swt. Ia pun memberi contoh jihad sebagai mahasiswa yaitu harus berujuang untuk mendapatkan ilmu. Sehingga dari perjuangan tersebut mereka tidak mengecewakan orang tua serta ilmu yang mereka peroleh dapat merubah kehidupan kearah lebih baik.

\subsection{Bersungguh-sungguh}

Jihad melawan hawa nafsu selanjutnya adalah bersungguh-sungguh. Jihad dalam arti bersungguhsungguh menurut Taufik adalah melakukan sesuatu karena diniatkan untuk Allah swt. Ia tidak sependapat dengan jihad yang di blow-up media masa sebagai aksi teroris. Karena baginya Islam adalah pedoman menjalankan aktivitas khidupan yang baik dan benar bukan untuk kekerasan. Jihad yang paling mudah dilakukan baginya ialah bagaimana ilmu yang didapat selama hidup dan kuliah dapat bermanfaat bagi orang lain.

Syaiful juga menjelaskan bahwa jihad berasal dari kata jahada yang artinya bersungguh-sungguh. Ia melanjutkan bahwa jihad adalah sesuatu yang diperjuangkan menurut aturan Rasul dan al-Qur'an. Jihad tidak bisa hanya dimaknai sebagai jihad perang, tapi bagaimana jihad dimaknai sebagai suatu yang baru seperti keilmuan yang mempunyai dampak kebermanfaatan pada orang lain.

\subsection{Berjuang}

Mar'ah yang merupakan kader IMM menjelaskan bahwa jihad hadir karena kecintaan terhadap Tuhan. Dimana pada awal mulanya ajaran Islam ditentang oleh kaum kafir namun Nabi Muhammad saw dan para pengikutnya tetap berusaha bagaimana ajaran Islam tetap dapat disebarkan. Sehingga menurutnya jihad adalah perjuangan, dimana perjuangan tersebut bertujuan untuk mencari ridha Allah swt. Ia juga tidak sependapat bahwa jihad digunakan sebagai dalil untuk melakukan kegiatan teroris. Karena jihad dilakukan untuk mendpatkan manfaat yang lebih besar.

Begitupun dengan Ma'arif yang mengatakan bahwa jihad berasal dari kata jahada yang berarti berjuang bukan berperang. Ia kemudian memaknai jihad binafsi yaitu jihad melawan hawa nafsu dan jihad lil ummah yaitu jihad yang dilakukan untuk umat. Ma'arif yang merupakan kader PMII menambahkan bahwa jihad sekarang dilakukan untuk kepentingan umat bukan untuk merugikan umat. Karena Islam hadir sebagai pedoman hidup agar menjadi keselamatn dunia dan akhirat.

\subsection{Menyebarluaskan Agama/Dakwah}

Nelly yang merupakan kader IMM menjelaskan bahwa jihad yang ia pahami di latar belakangi kedatangan Nabi Muhammad saw untuk menyebarkan kebaikan. Nelly melanjutkan bahwa jihad di zaman Nabi adalah perang, namun dalam konteks sekarang jihad tidak dapat diartikana hanya sebagai perang. Seperti dikatakannya bahwan jihad hadir untuk menyebarkan kebaikan, maka jihad ia maknai menyebarluaskan agama atau dakwah.

Begitu pula dengan Rijal, ia memaknai jihad dalam dua arti yakni dakwah dan fisik (perang). Namun dalam konteks kehidupan sekarang ia memaknai jihad sebagai dakwah. Ia berprinsip bahwa selagi kita mampu berdakwah itulah jihad. Karena dakwah merupakan kegiatan yang dilakukan untuk memberikan pemahaman kepada orang lain untuk berbuat baik dan benar. Ia pun menjelaskan jihad fisik (perang) hanya dapat dilakukan ketika dakwah sudah ditolak dan ada intitusi atau Negara yang telah membuat ketetapan atau peraturan bagaimana jihad dilakukan.

\subsection{Semangat}

Makna jihad pembaca terakhir adalah semangat. Satria yang merupakan mahasiswa FKIP memaknai jihad sebagai semangat dalam rangka menjalankan aktivitas-aktivitas kebaikan. Contohnya adalah jihad harta seperti bersedekah atau berbagi kepada orang lain. Baginya Islam adalah pedoman hidup yang mengatur segala kehidupan dari mulai bangun pagi hingga tertidur lagi. Maka wajar jika jihad termasuk cara dalam rangka memaknai Islam dalam kehidupan.

Jihad dalam tafsir al-Qur'an selanjutnya adalah jihad melawan setan serta jihad melawan kedzaliman dan kefasikan tidak diungkapkan oleh pembaca dalam memaknai jihad, disebabkan oleh karena pembaca hanya 
mempelajari dan memahami jihad dalam dua arti yakni jihad dalam arti sungguh-sungguh (jihad melawan hawa nafsu) dan jihad perang. Jihad dalam dua arti tersebut sangat jarang sering kali dibahas ataupun dipelajari pada waktu kajian keagamaan ataupun waktu berada di pembelajaran formal. Sehingga kebanyakan mahasiswa Universitas Mulawarman hanya mengetahui makna jihad dalam arti jihad hawa nafsu dan perang.

Pemahaman-pemahaman informan atau pembaca dalam menafsirkan jihad diatas sangat beragam dan bersifat individual. Perbedaan trajektori kehidupan selama proses kehidupan seperti latar belakang keluarga, pendidikan dan organisasi mewarnai secara beragam dalam pemaknaan jihad. Sehingga sebuah ranah kehidupan yang pernah atau sedang dialami oleh para informan sangat mempengaruhi informan dalam memberikan makna jihad.

\section{KESIMPULAN}

Jihad merupakan suatu teks yang ada dalam al-Qur'an. Jihad diartikan dalam dua kategori yakni jihad perang dan jihad melawan hawa nafsu. Jihad perang mempunyai arti tunggal sedangakan jihad melawan hawa nafsu memiliki ragam makna yaitu membela, melakukan kebaikan, usaha/kekuatan, bersungguh-sungguh, berjuang, menyebarluaskan agama (dakwah) dan semangat. Semua makna ragam jihad didasarkan dengan adanya niat dan tujuan hanya untuk Allah swt. Pemaknaan jihad pembaca atau informan dipengaruhi oleh trajektori kehidupan seperti latar belakang keluarga, pendidikan dan organisasi keagamaan yang mereka lalui atau yang sedang dialami karena merupakan modal untuk membangun persepsi-persepsi dalam memaknai teks jihad. Trajektori kehidupan dan tafsir teks memiliki hubungan erat dalam kaitan membangun persepsi makna secara subyektif. Hal itu disebabkan karena hermeneutik didasarkan pada premis bahwa teks mengatakan sesuatu tidak hanya mengenai dirinya melainkan dunia yang lebih luas mencakup tiga faktor yaitu dunia teks, dunia pemateri dan dunia pembaca. Dengan demikian membaca teks melalui jalan hermeneutik akan mendapatkan pemahaman yang jauh lebih luas dan lebih besar mengenai sebuah teks bukan hanya maknamakna secara literal.

\section{DAFTAR PUSTAKA}

Ar-Rifai, Muhammad Nasib. 1999. Kemudahan dari Allah: Ringkasan Tafsir Ibnu Katsir Jilid I. Jakarta: Gema Insani.

Ath-Thabari, Abu Ja'far Muhammad bin Jarir. 2007. Tafsir Ath-Thabari, Terj: Ahsan. Jakarta: Pustaka Azzam.

Azra, Azyumardi. 1996. Pergolakan Politik Islam dari Fundamentalisme, Modernisme hingga Post Modernisme. Jakarta: Paramadina.

Abdul Baqi, M. Fuad. 1346. Mufahras lil alfazi al-Qur'an al-Karim. Kairo: Dar Al-Kutub al-Misriah. Bahreisy, Salim dan Said Bahresyi. 1988. Terjemah Singkat Tafsir Ibnu Katsier.Surabaya: PT Bina Ilmu. Bleicher, Josef. 2003. Hermeneutika Kontemporer Terj. Ahmad Norma Permata. Yogyakarta: Fajar Pustaka. Chirzin, Muhammad. 1997. Jihad dalam al-Qur'an. Yogyakarta: Mitra Pustaka

Enizar, Dr.2007. Jihad, the Best Jihad for Muslims. Cet. 1, Jakarta: Amzah.

Esposito, John L. 1997.Political Islam: Beyond The Green Menace, Alih Bahasa: Sunarto, Yogyakarta: Pustaka Pelajar,

Nasr, S.H. 1994. Islam Tradisi di Tengah Dunia Modern. Bandung: Pustaka.

Raharjo, Dawam. 1996. Ensiklopedia Al-Qur'an (artikel tentang jihad). Jakarta: Paramadina.

Palmer, Richard, E. 2003. Hermeneutika: Teori Baru Mengenai Interpretasi.Yogyakarta: Pustaka Pelajar

Permata, Ahmad Norma. 2012. Hermeneutika Fenomenologis Paul Ricouer dalam Paul Ricouer, Teori Interpretasi; Memahami Teks, Penafsiran, dan Metodeloginya Terj. Musnur Henry. Jogjakarta: IRCiSOd, Cet. III

Qardhawi, Yusuf. 2009. Fiqih Jihad, Sebuah Karya Monumental Terlengkap tentang Jihad Menurut AlQur'an dan Sunnah. Bandung: Mizan Media Utama.

Ricoeur, Paul. 1991. from text to action; essays in hermeneutics, II. Evanston: Northwestern University Press. . 2003. Filsafat Wacana, Membelah Makna dalam Anatomi Bahasa, Terj. Musnur Hery. Yogyakarta: IRCiSod, Cet. II. 2014, Teori Interpretasi; Membelah Makna dalam Anatomi Teks. Yogyakarta: IRCiSod.

Silverstone, Roger. 1994. Television and Society. London: Routledge. Simms, Karl. 2003. Paul Ricoeur. London: Routledge.

Tim BPPAI. 2013. Buku Pintar Praktikum Agama Islam Universitas Mulawarman. Samarinda: BPPAI Pres. 